\title{
DIGITAL TRANSFORMATION AS A FACTOR OF ENSURING COUNTRY COMPETITIVENESS: MOLDOVA CASE ANALYSIS
}

\author{
Daiva Bickauske \\ Mykolas Romeris University, Lithuania \\ E-mail:daiva.bickauske@gmail.com \\ Saulius Kromalcas \\ Mykolas Romeris University, Lithuania \\ E-mail: saulius.kromalcas@gmail.com \\ Zaneta Simanaviciene \\ Mykolas Romeris University, Lithuania \\ E-mail: zasiman@mruni.eu \\ Larysa Sergiienko \\ Zhytomyr Polytechnic State University, Ukraine \\ E-mail:sergiienko.lv@gmail.com \\ Tetiana Baranovska \\ Zhytomyr Polytechnic State University, Ukraine \\ E-mail: tatyana_baranovs@ztu.edu.ua \\ Submission: 8/24/2021 \\ Accept: 9/26/2021
}

IJTM\&P

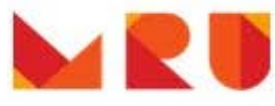

MYKOLAS ROMERIS UNIVERSITY

\section{ABSTRACT}

The digital transformation is now a reality in Moldova, as Moldova has begun to transfer social, legal, and civil service delivery online. Sped-up digitalization can be expected to create new business models and opportunities for digital jumping in traditional industries. The Coronavirus crisis has highlighted the need for support and investments in digital transformation and effective digital governance, especially to guarantee the continuity and delivery of core government functions. The digital transformation is changing not just business models but the methods of production and distribution and the industry's competitiveness. Further analysis has been made to generate specific steps/recommendations regarding the digitization of the Moldova industry. The interview with experts who work closely in digitalization or competitiveness was done, and the SWOT analysis was done. Based on the research made, the 
INDEPENDENT JOURNAL OF MANAGEMENT \& PRODUCTION (IJM\&P)

http://www.ijmp.jor.br

v. 12, n. 6, Special Edition ISE, S\&P - November 2021

ISSN: 2236-269X

DOI: 10.14807/ijmp.v12i6.1779

recommendations for Moldova were prepared and presented in this article.

Keywords: digitalization; manufacturing; Moldova, competitiveness

\section{INTRODUCTION}

Moldova is a small lower-middle income economy. It is one of the poorest countries in Europe. Moldova has made significant progress in promoting inclusive growth and reducing poverty and since the early 2000s. Global Competitiveness Index report covering 141 economies measures national competitiveness-defined as the set of institutions, policies, and factors determining the level of productivity. Moldova was also ranked 86th (The Global Competitiveness Index 4.0 rankings report, 2019).

The majority of the entrepreneurs recognize that digital transformation is an excellent opportunity for development and competitiveness (Ślusarczyk, 2018). The strengthening of digitalization processes puts additional competitiveness pressures on manufacturing businesses. Although digital transformation is a new concept in manufacturing (Okano, 2021), to maintain competitiveness, steps towards the digitalization of industry have to be implemented.

\section{LITERATURE REVIEW}

\subsection{The concept of digital transformation}

Digital transformation can be defined as changes in jobs and income creation strategies, applying a flexible management model standing against the competition, quickly meeting changing demands. It is a process of reinventing a business to digitalize operations and formulate extended supply chain relationships. Practical use of the internet in design, manufacturing, marketing, selling, presenting, and data-based management model (Schallmo, 2018).

The authors highlight the importance of digitization in the manufacturing sector and claim that companies need to implement the latest technology (Wang, 2016).

The digital transformation process requires companies to transform every day and be concerned with items such as customers, business models, new technologies, agile methods, and innovations (Okano, 2021). Considering that technologies have been completely changing the industry and digital transformation is expected to have a vast impact on almost any industry, digitalization can bring new opportunities for SMEs by improving the entire value chain (Kilimis, 2019). Digitization strengthens the potential for quality improvement, flexibility, and productivity (Hoellthaler \& Braunreuther, 2018). 
INDEPENDENT JOURNAL OF MANAGEMENT \& PRODUCTION (IJM\&P)

http://www.ijmp.jor.br

v. 12, n. 6, Special Edition ISE, S\&P - November 2021

ISSN: 2236-269X

DOI: 10.14807/ijmp.v12i6.1779

Digital transformation is adopting disruptive technologies to increase productivity, value creation, and social well-being (Duarte, 2018).

Ulas (2019) had identified several factors expediting digital transformation that include, among others, globalization, advancement of technology and innovation, electronic commerce, and social media. Experts highlight four areas where digitization technologies have the most significant impact: productivity, revenue growth, employment, and investment (Russmann, 2015) (Table 1).

Table 1: Impact of digitization on German macroeconomics

\begin{tabular}{|l|l|}
\hline Area & Scale \\
\hline Productivity & $\begin{array}{l}\text { More and more companies will have to deploy digital } \\
\text { technologies over the next ten years, increasing the productivity } \\
\text { of the manufacturing sector. }\end{array}$ \\
\hline Income & $\begin{array}{l}\text { The demand for new products, new personalized products will } \\
\text { increase revenue growth. }\end{array}$ \\
\hline Employment & $\begin{array}{l}\text { Production growth will increase employment by around 6\%. The } \\
\text { demand for engineering in the engineering sector will increase by } \\
10 \% \text {. Accelerating automation will replace low-skilled workers. } \\
\text { The growing demand for IT skills will increase the demand for } \\
\text { employees with competencies in the IT sector. }\end{array}$ \\
\hline Investment & $\begin{array}{l}\text { By adapting production processes to Industry } 4.0 \text { trends, German } \\
\text { manufacturing companies should invest around } € 250 \text { billion. }\end{array}$ \\
\hline
\end{tabular}

Source: based on Russmann, 2015

Digitization will make a significant impact on manufacturing companies, workforce, and companies supplying new manufacturing systems.

\subsection{Country competitiveness definition}

According to Leão de Miranda (2021), the term competitiveness has historically been used to relate companies and nations in terms of costs. Analyzing the concept of competitiveness, most experts agree that competitiveness is a highly complex and multifaceting phenomenon, as is the competition itself, the evaluation of which requires considering the results achieved in various areas. The concept of competitiveness begins with trade theory (Smith, 1937).

Porter (1990) first introduced the idea of competitive advantage. Competition based on innovation, according to Porter (1980), is the highest stage in the development of the competitiveness of the country's economy, characterized not only by the application and improvement of foreign equipment and technology", but also by "the creation of new examples, creative development of the product range, production processes, sales organization system." 
Porter (2012) identifies four stages of the competitiveness of the national economy, corresponding to four main drivers of its development: factors of production, investment, innovation, and wealth. At the same time, the first three stages are characterized by an increase in the competitiveness of the country's economy.

Krugman's (1994) position on the country's competitiveness is based on Ricardo's classic theory (particularly the theory of comparative superiority).

According to Krugman (1994), only companies trade and compete. International trade allows companies to develop a division of labor and enables the growth of the economies of all countries. Analyzing the concept of the country's competitiveness (Rakauskiené, 2013) distinguishes three approaches:

$\square$ The country's competitiveness is a successful foreign trade of the country;

$\square$ The country's competitiveness is the productivity of the country;

$\square$ The country's competitiveness is the ability to ensure the well-being of the country's population.

A broad notion of competitiveness refers to the inclination and skills to compete, win and retain a market position, increase market share and profitability, and eventually consolidate commercially successful activities (Filó, 2007).

The model of systemic competitiveness of Esser (2007) is suitable for analyzing competitiveness. According to it, the country's competitiveness consists of four levels:

a) Meta-economic level: socio-cultural factors; value system; the country's politicaleconomic clout; capacity to formulate strategies and policies;

b) Macroeconomic level: budgetary policy; monetary policy; fiscal policy; competition policy; trade policy;

c) Meza economic level: infrastructure policy; educational policy; industrial policy; environmental policy; regional policy; import and export policy;

d) Microeconomic level: management competence; company strategy.

The World Economic Forum (WEF) produces one of the best-known competitiveness indices - the Global Competitiveness Index (GCI, 2019). The national economy competitiveness reflects the state of its institutions, policies, and factors that determine the productivity level of the economy, its growth level, and the prosperity level achievable for a particular country (World Economic Forum, 2017).

Under conditions of intense business globalization, pronounced competition, dramatic demographics (Marinović, 2017), economic and technological changes, country economy 
INDEPENDENT JOURNAL OF MANAGEMENT \& PRODUCTION (IJM\&P)

http://www.ijmp.jor.br

v. 12, n. 6, Special Edition ISE, S\&P - November 2021

ISSN: 2236-269X

DOI: 10.14807/ijmp.v12i6.1779

competitiveness is gaining importance. The WEF definition links micro- (firm-level) to macro- (country-level) competitiveness.

The WEF's national competitiveness assessment is based on the Global Competitiveness Index (2019), which comprises several indicators measuring certain aspects of competitiveness, grouped into composite factors in terms of content, which form 12 groups of competitiveness factors (Table 2).

Table 2: The content of the Global Competitiveness Index

\begin{tabular}{|c|c|}
\hline Groups of Factors & Factors \\
\hline Institutions & $\begin{array}{c}\text { Public institutions (property rights; ethics and corruption; } \\
\text { abuse of influence; government efficiency; security); } \\
\text { private institutions (corporate ethics, accountability) }\end{array}$ \\
\hline Infrastructure & $\begin{array}{c}\text { Transport infrastructure; electricity and telephony } \\
\text { infrastructure }\end{array}$ \\
\hline \multicolumn{2}{|c|}{ Macroeconomic environment } \\
\hline Good health and primary education & Health; primary education \\
\hline Higher education and training & Scope of education, quality of education, staff training \\
\hline Product market efficiency & $\begin{array}{c}\text { Competitiveness (internal competition; foreign } \\
\text { competition); quality of demand conditions }\end{array}$ \\
\hline Labour market efficiency & Flexibility; efficient use of talents \\
\hline Growth of financial markets & Efficiency; reliance, loyalty \\
\hline Ability to harness progressing technology & Technology uptake; the use of ITT \\
\hline Market size & Local market size; foreign market size \\
\hline Business literacy \\
\hline Innovation \\
\hline
\end{tabular}

Global Competitiveness Index report (2019) covering 141 economies measures national competitiveness-defined as a set of policies, institutions, and factors that determine the level of productivity. Moldova was also ranked $86^{\text {th }}$.

The research objects of researchers studying competitiveness are different. Therefore, the analyzed and described factors of competitiveness are different. As a reason, there is no single and universally accepted methodology for assessing the country's competitiveness. Competitiveness is a set of factors, institutions, and policies that determine the level of productivity.

\subsection{Digital country competitiveness}

The Institute for Management Development (IMD, 2017), an independent academic institution with Swiss roots and global reach, started the World Digital Competitiveness measuring (2017).

Based on IMD, World Digital Competitiveness (WDC, 2017) analyzes and ranks to which extent countries adopt and explore digital technologies leading to transformation in government practices, business models, and society. 
IMD World Digital Competitiveness Ranking measures the capacity and readiness of 63 economies to adopt and explore digital technologies as a critical driver for economic transformation in business, government, and broader society.

Based on institute research, the methodology of the WDC ranking defines digital competitiveness into three main factors: knowledge, technology, future-readiness. Moldova was not included in the digital latter ranking.

\subsection{General situation of Moldova}

Business confidence in Moldova is low, while the macroeconomic framework remains vulnerable. Transparency, accountability, and corruption are crucial concerns and external budget support, which is based on an agreement with the International Monetary Fund, has a high level of conditionality. To improve this situation, the Moldova government must carry out critical economic reforms and create a rule-based, effective and accountable environment for businesses. However, the recent election of Parliament shows that country is split between pro-Russian and pro-European political powers. However, neither of these groups didn't gain the majority, which puts the country in a situation of political instability.

Moldova's large-scale emigration combined with decreasing fertility rates deserves particular attention. It has led to an alarming decline in the population and accelerated the aging of society. Around $15 \%$ or 500000 of the country's population live outside Moldova. It puts pressure on the pension system and the country's long-term competitiveness.

\subsection{Statistics of Moldova GDP}

The influence of the industry sector on Moldova's GDP is around 15\%. Industry sector in Moldova consist of mining and quarrying (B); manufacturing industry (C); production and distribution of electricity and heat, gas, hot water and air conditioning (D); distribution of water, sanitation, waste management, decontamination activities (D).

The distribution and influence of these segments on Moldova GDP can be seen in Table 3 (Statbank, 2020).

According to the statistics department of Moldova, the industry sector was on the rise during the period of 2014-2015 and started to decrease from 2016 to 2019 (Statbank, 2020).

Out of four segments, manufacturing is by far the most significant sector, and it saw the most significant increase over the period of 2014-2019.

Sectors D and E showed an upward trend. However, it wasn't substantial compared to manufacturing. Last but not least, the Mining and quarrying sector remains the same. 
INDEPENDENT JOURNAL OF MANAGEMENT \& PRODUCTION (IJM\&P)

http://www.ijmp.jor.br

v. 12, n. 6, Special Edition ISE, S\&P - November 2021

ISSN: 2236-269X

DOI: 10.14807/ijmp.v12i6.1779

Table 3: Contribution of economic activities in the GDP formation, \%

\begin{tabular}{|l|c|c|c|c|c|c|}
\hline \multicolumn{1}{|c|}{ Year } & $\mathbf{2 0 1 4}$ & $\mathbf{2 0 1 5}$ & $\mathbf{2 0 1 6}$ & $\mathbf{2 0 1 7}$ & $\mathbf{2 0 1 8}$ & $\mathbf{2 0 1 9}$ \\
\hline (B) Mining and quarrying & $0.3 \%$ & $0.3 \%$ & $0.2 \%$ & $0.2 \%$ & $0.2 \%$ & $0.3 \%$ \\
\hline (C) Manufacturing and distribution of & $11.6 \%$ & $12 \%$ & $11.9 \%$ & $11.6 \%$ & $11.2 \%$ & $10.6 \%$ \\
\hline $\begin{array}{l}\text { (D) Production and } \\
\text { electricity and heat, gas, hot water and air } \\
\text { conditioning }\end{array}$ & $2.5 \%$ & $2.5 \%$ & $2.5 \%$ & $2.4 \%$ & $2.5 \%$ & $2.3 \%$ \\
\hline $\begin{array}{l}\text { (E) Distribution of water, sanitation, } \\
\text { waste management, decontamination } \\
\text { activities }\end{array}$ & $0.8 \%$ & $0.8 \%$ & $0.8 \%$ & $0.8 \%$ & $0.8 \%$ & $0.8 \%$ \\
\hline
\end{tabular}

The volume of industrial production indicates annual growth in this sector (Table 4). Since 2010, industrial production has increased by 40,7\%. This pattern is evident in the manufacturing segment, which, compared to 2010, rose by $52.2 \%$. The mining and quarrying sector reached its highest point in 2011. Since then, there is no general pattern that could define this sector's growth dynamics.

The amount of production during 2018 reached the volume of 2010. Last but not least, production output in electricity and heat, gas, hot water, and air conditioning segment increased by $7,5 \%$. There is no statistical information about water, sanitation, waste management, decontamination segment (Statbank, 2021).

Table 4: Volume indices of industrial production, $2010=100 \%$

\begin{tabular}{|l|c|c|c|c|c|c|c|c|c|c|}
\hline \multicolumn{1}{|c|}{ Year } & 2011 & 2012 & 2013 & 2014 & 2015 & 2016 & 2017 & 2018 & 2019 & 2020 \\
\hline Industry - total & 113.4 & 110.7 & 120.2 & 129.0 & 129.9 & 131.1 & 135.6 & 140.7 & 143.7 & 135.5 \\
\hline $\begin{array}{l}\text { (B) Mining and } \\
\text { quarrying }\end{array}$ & 127.2 & 100.3 & 122.6 & 122.9 & 111.6 & 94.3 & 90.2 & 100.3 & 97.4 & 107.3 \\
\hline $\begin{array}{l}\text { (C) Manufacturing } \\
\text { (D) Production and } \\
\text { distribution of } \\
\text { electricity and heat, } \\
\text { gas, hot water and } \\
\text { air conditioning }\end{array}$ & 113.9 & 113.2 & 125.2 & 135.9 & 139.0 & 141.5 & 148.1 & 152.2 & 157.1 & 145.8 \\
\hline
\end{tabular}

The main factors which led to the growth of the industrial sector are: the expansion of the foreign investor's activities, especially in the automotive industry, the positive developments in the agricultural sector that stimulated the growth of the food industry, the increase of domestic and foreign demand for national industrial products, due to the opening of the foreign and the implementation of the international economic cooperation agreements.

Industry sector production output is rising; however, this sector's amount of labour force is relatively stable (Table 5). Compared to the entire country, the share of employees in 
INDEPENDENT JOURNAL OF MANAGEMENT \& PRODUCTION (IJM\&P)

http://www.ijmp.jor.br

v. 12, n. 6, Special Edition ISE, S\&P - November 2021

ISSN: 2236-269X

DOI: 10.14807/ijmp.v12i6.1779

the industry is relatively stable - around $12 \%$. Even though the number of employees was regular, monthly average earnings rose during the last five years (Statbank, 2021).

Compared to the entire Moldova economy, wages in the industry sector are more significant. However, this industry sector average is distorted by Electricity, gas, steam, and air conditioning supply segment (D).

In general, production output is rising, but the fact that industry is dominated by resources-intensive and low-medium tech companies combined with increasing labour costs means that the Moldova industry sector's competitiveness could have competitiveness-related issues.

Table 5: Employed population

\begin{tabular}{|l|c|c|c|c|c|c|c|c|c|c|}
\hline Year & 2010 & 2011 & 2012 & 2013 & 2014 & 2015 & 2016 & 2017 & 2018 & 2019 \\
\hline $\begin{array}{l}\text { Industry } \\
\text { \% of total }\end{array}$ & $\mathbf{1 8 , 6 4}$ & $\mathbf{1 8 , 7 5}$ & $\mathbf{1 9 , 2 8}$ & $\mathbf{1 7 , 6 9}$ & $\mathbf{1 7 , 9 0}$ & $\mathbf{1 7 , 8 5}$ & $\mathbf{1 7 , 1 4}$ & $\mathbf{1 6 , 6 5}$ & $\mathbf{1 9 , 4 0}$ & $\mathbf{2 1 , 7 1}$ \\
\hline
\end{tabular}

Despite its growth and importance to the country's economic performance, the manufacturing sector has to improve.

The structure of the manufacturing segment is dominated by resource-based businesses, which account for almost half of manufacturing companies (45.2\%). Low-tech and medium-tech manufacturing companies account respectively $26.1 \%$ and $25.2 \%$.

The share of high-tech companies is extremely low and makes up only 3.5\% of all manufacturing businesses (Competitive Industrial Performance Index, 2020).

Finally, the manufacturing sector composition is mainly dominated by food and beverages production. This segment accounts for $40.4 \%$ of all manufacturing production. The other four most significant segments are wearing apparel, fur (10.9\%); non-metallic mineral products $(9.4 \%)$.

\subsubsection{Business structure}

Data of 2016 shows a total of 51,600 SMEs in Moldova or $98.7 \%$ of total registered enterprises (Table 6). 20,300 or almost $40 \%$ of the total number of SMEs are active in the wholesale and retail trade. The second largest category represented by SMEs is the "other" with manufacturing and professional services, scientific and technical activities representing the third largest category with an equal amount of 4,400 SMEs each (or $8.5 \%$ of the total number of SMEs).

SMEs sector in 2016 employed 313,500 employees or 61.2\% of the entire workforce. However, it should be noted that micro-enterprise is the most significant segment in SMEs 
INDEPENDENT JOURNAL OF MANAGEMENT \& PRODUCTION (IJM\&P)

http://www.ijmp.jor.br

v. 12, n. 6, Special Edition ISE, S\&P - November 2021

ISSN: 2236-269X

DOI: 10.14807/ijmp.v12i6.1779

structure and makes up $85.1 \%$ of it. Despite that, a number of employees in the SMEs segment are distributed relatively equally. Small and medium-size enterprises contribute a total of $31.4 \%$ of GDP in Moldova.

In terms of income, SMEs have generated a total of nearly $€ 2.5$ billion in 2016 . The main contributing sectors are wholesale and retail trade with approximately $49 \%$ and manufacturing industry with approximately $11 \%$.

Table 6: Indicators related to the SME activity in 2016

\begin{tabular}{|l|c|c|c|c|}
\hline Indicator & $\begin{array}{l}\text { Number of units, } \\
\text { thousand }\end{array}$ & $\begin{array}{l}\text { Percentage of total } \\
\text { in RM \% }\end{array}$ & $\begin{array}{l}\text { Number of people, } \\
\text { thousand }\end{array}$ & $\begin{array}{l}\text { Percentage of total } \\
\text { in RM \% }\end{array}$ \\
\hline Total SMEs of which: & 51.6 & 98.7 & 331.5 & 61.2 \\
\hline $\begin{array}{l}\text { Medium-sized } \\
\text { enterprises }\end{array}$ & 1.3 & 2.5 & 101.5 & 19.8 \\
\hline Small enterprises & 5.8 & 11.0 & 107.2 & 20.9 \\
\hline Micro enterprises & 44.5 & 85.1 & 104.8 & 20.5 \\
\hline
\end{tabular}

\subsubsection{Local ecosystem}

Moldovan government structure in relation to industry digitisation together with research and development is quite broad. The development of the R\&D system of Moldova underwent different phases and was administered by a number of government departments and institutions, however, since 2004, this role is dedicated to the Moldovan Academy of Sciences (ASM). The Academy is the main policy-making institution and fulfills, to a large extent, the role of a Ministry of Science.

The president of ASM is a member of the Government. It is an elected eminent national scientist who enjoys full independence from political views. ASM works as the research policy-making body, it manages most of the public R\&D funds, and is the main research performing institution in the country. However, various experts emphasize that this situation results in a clear institutional conflict of interest since it places ASM as a policymaker and funding agency while being at the same time the major beneficiary of the research funds.

Besides Moldovan Academy of Science, there are also Moldovan ministries, which are directly involved in the management of research and innovation policy/or funding. The Ministry of Finance defines the allocation of government resources for R\&I activities. The Ministry of Economy is also involved and deals with innovation and technology transfers in the business sector.

Ministry of Environment is responsible for allocation of moderate R\&D funding through its National Environment Fund (FEN). Besides that, Ministry of Health also disposes 
INDEPENDENT JOURNAL OF MANAGEMENT \& PRODUCTION (IJM\&P)

http://www.ijmp.jor.br

v. 12, n. 6, Special Edition ISE, S\&P - November 2021

ISSN: 2236-269X

DOI: 10.14807/ijmp.v12i6.1779

several subordinated health research institutions. Last but not least, Ministry of Education oversees Moldova higher education sector in order to strengthen the research capacities at universities.

Besides governmental level, Parliament of Moldova is also involved in R\&D affairs. Within Parliament, the Committees on Culture, Education, Research, Youth, Sport and Massmedia are responsible for the analysis and improvement of draft acts related to science and innovation.

Moldovan Academy of Science and its subordinated bodies are the main stakeholders for policy implementation. There is a Centre for Fundamental and Applied Research Funding (CFCFA) within ASM, established in 2012 for the allocation of public funding for fundamental and applied research and which manages the main Moldovan funding programs.

Other institutions are Moldovan Agency for Innovation and Technology Transfer (AITT), which is funding institution and responsible for supporting innovation and technology transfer. In addition, the Ministry of Economy also established Organization for SME sector development (ODIMM), which is responsible to provide support for SMEs in Moldova.

One more important agency operating in innovation system is the National Council for Accreditation and Attestation (CNAA). This organization is highly relevant for institutions wanting to become eligible for public R\&I funding. These have to undergo an evaluation and accreditation procedure, conducted by the CNAA.

Accreditation is granted for a period of up to five years. Under the Code on Science and Innovation all research organizations accredited by the CNAA become members of the Academy of Science. There should be noticed a significant difference between capital Chisinau and the rest of the country in regards to CNAA activity. During the period of 20052013, CNAA accredited 60 organizations, but only three were situated outside Chisinau.

Last but not least, it also worth mentioning innovation agencies operating outside the ASM structure. These are the State Agency on Intellectual Property of the Republic of Moldova (AGEPI) and the National Environmental Fund (FEN). First institution takes care of protection of intellectual property and the latter one manages dedicated research funding under the Ministry of Environment.

Majority of the entrepreneurs recognize the industry digitalization as a great opportunity for development and improvement in competitiveness (Ślusarczyk, 2018). The strengthening of digitalization processes may put additional competitiveness pressures on 
manufacturing businesses. In order to maintain the competitiveness, the industry should step towards the digitalization.

Digitization offers the potential for quality improvement, flexibility and productivity (Hoellthaler \& Braunreuther, 2018).

In order to generate specific steps/recommendations in regard to the digitisation of Moldova industry, the further analysis have been made.

\section{DATA AND METHODOLOGY}

SWOT Analysis is a decision-making method, and it has been widely used in the management process. SWOT analysis has successfully been applied in identifying and solving problems (Mainali, 2011).

SWOT analysis was applied to evaluate the current situation and future possibilities for the Moldova industry sector. This method is selected because it can incorporate the present conditions (through strengths and weaknesses) and the future conditions (through opportunities and threats).

The research adopts an expert interview approach to gather information. The main input for the SWOT analysis was knowledge and information collected through interviews with relevant experts.

Experts interviews is a popular method of gathering information in various fields of political and social science. It can provide insight and valuable knowledge in the relevant field. It is also considered an efficient and concentrated method of gathering data, especially in the exploratory phase (Bogner et al., 2009).

Selecting the relevant experts is essential to gather usable information. The experts interviewed for this research compose of people who work closely in digitalization or competitiveness.

Also, the triple helix approach was used to involve experts from Government, industry, and academia.

The list of their qualifications is provided in Table 7.

The interview was conducted through one-to-one interviews. The responses were collected from the respondents using a mixture of open-ended and scaled questions. To provide a quantitative assessment, the respondents were asked to rank their preferred option using the scale of 1 to 5 ( 1 - most unsuitable, 5 - most suitable). 
INDEPENDENT JOURNAL OF MANAGEMENT \& PRODUCTION (IJM\&P)

http://www.ijmp.jor.br

v. 12, n. 6, Special Edition ISE, S\&P - November 2021

ISSN: 2236-269X

DOI: 10.14807/ijmp.v12i6.1779

Table 7: Qualifications of experts

\begin{tabular}{|c|l|l|}
\hline Respondents & \multicolumn{1}{|c|}{ Qualifications } & \multicolumn{1}{|c|}{ Field of expertise } \\
\hline 1 & $\begin{array}{l}\text { Digitalisation expert at the governmental public agency with more than } 20 \\
\text { years of experience in digitalisation area. Male, 52 years old }\end{array}$ & Government \\
\hline 2 & Professor of management of Vilnius Tech Universitv. Male, 35 vears old & Academic researcher \\
\hline 3 & Professor of Economics of Mykolas Romeris University. Femaile, 66 years & Academic Researcher \\
\hline 4 & Coordinator of Digital innovation hub in Lithuania. Female, 41 years old & Industry \\
\hline 5 & CEO of Science and technology park in Lithuania. Male, 53 years old & Academic Researcher \\
\hline 6 & CEO of regional business association. Male, 44 years old & Industry \\
\hline
\end{tabular}

Source: compiled by the authors

\section{RESULTS AND DISCUSSIONS}

In terms of its positive qualities (strengths and opportunities), the respondents emphasise on different aspects of Moldova industry sector

In order to understand the current situation and future possibilities for Moldova industry sector, SWOT analysis has to be performed (Table 8).

Table 8: SWOT analysis

\begin{tabular}{|c|c|}
\hline $\begin{array}{l}\text { Strengths } \\
\text { - Industry sector and manufacturing segment output is } \\
\text { rising; } \\
\text { - Well-developed, consistently updated public and } \\
\text { private ICT infrastructure; } \\
\text { - Moldova ranks 6th worldwide translating its } \\
\text { innovation inputs into outputs } \\
\text { - Digitization solutions providers can supply a wide } \\
\text { range of digitization services (by increasingly } \\
\text { participating in local and global value chains, } \\
\text { related to ICT, robotics, automation, electronics, } \\
\text { cyber security, digitization solutions providers can } \\
\text { offer services ranging from standard adaptable } \\
\text { services to specialized services); } \\
\text { - Moldova ranked 5th in regards to business friendly } \\
\text { environment, according to fDi Manufacturing } \\
\text { Locations of the Future 2018/19 ranking TOP } 10 \\
\text { Manufacturing Countries of the Future 2018/19. }\end{array}$ & $\begin{array}{l}\text { titutions which whose competences overlap; } \\
\text { IEs still lack appropriate education } \\
\text { trepreneurial skills, understanding of HR ren }\end{array}$ \\
\hline
\end{tabular}


Information and Communication Technologies (ICT), which has gained weight similar to that of other CIS countries;

- Integration with EU: Moldova is a member of Eastern Partnership with EU and has an Association Agreement with European Union signed in 2014. Integration with EU will provide various advantages and support measures. Country participate in Horizon 2020 and Smart Specialization Strategy;

- International financial institutions readiness to support transformation processes;

- Opportunities for business to get to know and use more financial support and measures;

- In 2017 Moldova launched a number of reforms such as labor code or labor migration, however, the implementation and the effects of reforms are still unclear;

- Clusters policy is present in some policy documents. Moldova is on the right track, understanding the importance of clustering, however there is a long way to go in regards to the development of it.
- Shortage of talents due to migration and flight of human capital ("brain drain") (internal migration from regions to cities; emigration from Moldova to foreign countries);

- Deficit of professionals due to the current demographic situation;

- The higher education institutions are not capable of preparing suitable specialists (due to the inappropriate digital technologies infrastructure aimed at study; due to insufficient lecturers'/vocational teachers' qualifications in industry digitization matters);

- Inflexible regulation of work conditions regarding organization and installation of digital workplaces in companies;

- A fragmented and underdeveloped innovation support and innovation consulting services system that otherwise would make the creation and installation of digital innovations in industry more effective

Source: compiled by the authors

Based on it, recommendations and measures will be drawn.

\subsection{A Vision of digitalized Moldova industry}

Following the SWOT, the vision concerning the future of digitalized Moldova manufacturing sector can be established.

\section{Internal/Company-related factors:}

- Moldova is dominated by relatively small, smart and agile factories manufacturing higher value-added products for niche markets; flexible organizations can diversify rapidly to meet changing market needs.

- Moldovan capital and foreign capital companies operating in Moldova are deeply embedded in international value chains through ownership, production partners and realization markets.

- Moldova is a 'testbed' for new cutting-edge technological solutions created across Europe, Japan and USA - first deployed in Moldova industry for demonstration purposes; then, spread across all of Europe. Therefore, Moldovan solution providers and solution integrators always work with the latest technologies.

\section{External/Environmental factors:}

- Moldova provides access to a variety of specialists that the industry demands, as required, for digitisation. 
- Moldova provides opportunities for lifelong learning, non-formal education and competence enhancement, through industry-university/college-cooperation.

- Moldova is a destination of choice for talented professionals from abroad and international students (who stay and work in Moldova after their studies).

- Moldova remains in the top European states that continually sustain a state-of-the-art infrastructure for industry development (accessible transportation, logistics, and energy in every corner of the country, as well as ICT appropriate to the 5G network and Industry 4.0).

\subsubsection{Strategic Pillars Supporting the Vision}

Moldova industry digitisation action plan should be supported by 4 pillars: Knowledge, People, Infrastructure and Environment. Each of these foundations encompasses distinct target priorities identified by experts and addressed by specific policy measures.

Knowledge considers technologies and business models that will become integrated through value chains.

People refers to policy-makers, researchers and creators, enablers, and intermediaries that will play a critical role in the digitisation of industry along the private sector and investors.

Infrastructure regards services infrastructure, demonstration infrastructure, and $R \& D$ infrastructure which, when combined, will provide the best possible conditions for manufacturing innovation.

Environment concerns the legal and regulatory environment, standards, and incentives system that will embed industry in a smoothly performing facilitation network within the local ecosystem.

Strategic pillars cover areas that are in most need of action in order to achieve the digitalised industry's vision (Figure 1).

To overcome these challenges, digital competences and skills must be developed to assist companies in creation, adoption and implementation of digital solutions. By using opportunities provided by digitisation, companies would become enabled to increase their productivity, production value and to internationalise.

There are the key measures to accomplish that (Table 9): 
INDEPENDENT JOURNAL OF MANAGEMENT \& PRODUCTION (IJM\&P)

http://www.ijmp.jor.br

v. 12, n. 6, Special Edition ISE, S\&P - November 2021

ISSN: 2236-269X

DOI: 10.14807/ijmp.v12i6.1779

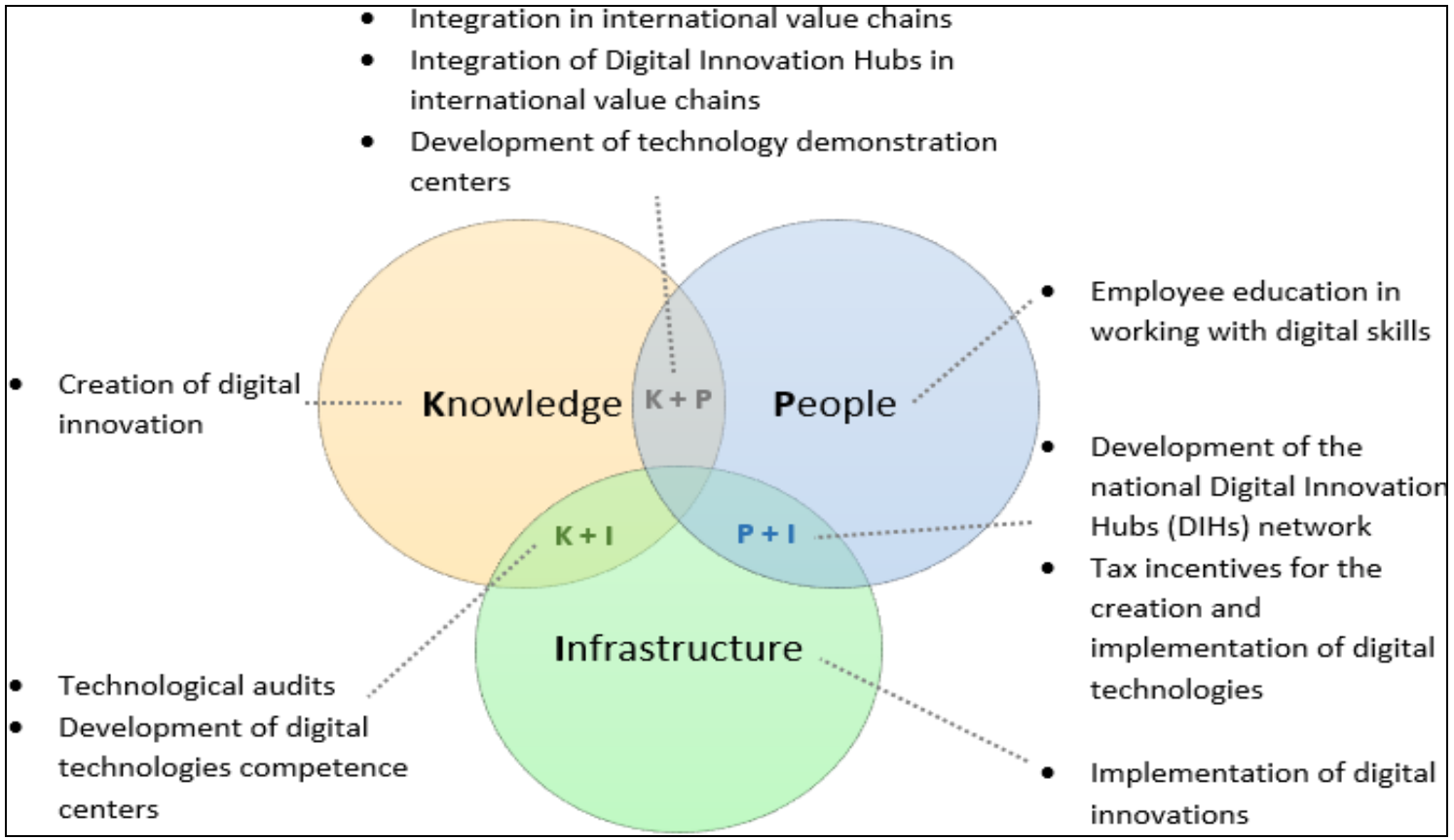

Figure 1: Strategic pillars

Actions are designed to reflect 4 strategic ares, where the action is most needed: Knowledge,

People, Infrasctruture and Environment.

$\begin{array}{llll}\text { K1 }- \text { Technologies } & \text { P1 - Policy-makers } & \text { I1 - Services } & \text { E1 - Legal \& } \\ \text { K2 - Business } & \text { P2 - Researchers and } & \text { Infrastructure } & \text { Regulatory } \\ \text { Models } & \text { Creators } & \text { I2 - Demonstration } & \text { Environment } \\ & \text { P3 - Enablers } & \text { Infrastructure } & \text { E2 - Standards } \\ & \text { P4 - Intermediaries } & \text { I3 - R\&D } & \text { E3 - Incentives } \\ & & \text { Infrastructure } & \end{array}$

Table 9: List of measures

\begin{tabular}{|l|l|c|}
\hline No & Measures & $\begin{array}{c}\text { Pillars and priorities } \\
\text { (K, P, I, E) }\end{array}$ \\
\hline 1. & Creation of digitisation technologies & $\mathrm{K} 1$ \\
\hline 1.1. & Preparation of the policy mix for implementation of the new S3 E1 \\
\hline 1.2. & Implementation of the new S3 & $\mathrm{K} 1$; E1 \\
\hline 2. & Adoption (import) of digitisation technologies & $\mathrm{K} 1$ \\
\hline 2.1. & Identification and wider implementation of national and international good practice \\
\hline 2.2. & $\begin{array}{l}\text { Identification of pilot projects to transfer and to test those technologies defined as } \\
\text { most influential in the digitisation of local industry that could later lead to whole } \\
\text { industrial development }\end{array}$ & $\mathrm{K} 1$ \\
\hline 2.3. & Preparation of measures for larger-scale implementation of successful pilots & $\mathrm{K} 1$ \\
\hline 3. & $\begin{array}{l}\text { Joining international technology development value chains (for instance, } \\
\text { international clusters, international R\&D programmes) }\end{array}$ & $\mathrm{K} 1$ \\
\hline 3.1. & A continuous call for an international partner search measure & $\mathrm{K} 1 ; \mathrm{E} 3$ \\
\hline
\end{tabular}


INDEPENDENT JOURNAL OF MANAGEMENT \& PRODUCTION (IJM\&P)

http://www.ijmp.jor.br

v. 12, n. 6, Special Edition ISE, S\&P - November 2021

ISSN: 2236-269X

DOI: 10.14807/ijmp.v12i6.1779

\begin{tabular}{|c|c|c|}
\hline 3.2. & $\begin{array}{l}\text { Preparation of co-financing schemes describing how Moldova will support entities } \\
\text { accepted into international consortiums and are awarded grants that require co- } \\
\text { financing }\end{array}$ & K1; E3 \\
\hline 3.3. & $\begin{array}{l}\text { Preparation of financing schemes for the funding of cross-sectoral initiatives for } \\
\text { participation (incl. operational costs) in international networks, clusters, platforms, } \\
\text { working/topic groups, etc. }\end{array}$ & K1; E3 \\
\hline 4. & $\begin{array}{l}\text { Development of industrial graduate programmes in areas related to industry } \\
\text { digitisation }\end{array}$ & K1; P2 \\
\hline 5. & Development of safe and (cyber) secure technologies by design & K1 \\
\hline 6. & $\begin{array}{l}\text { Creation of business models oriented towards integration in international value } \\
\text { chains }\end{array}$ & $\mathrm{K} 2$ \\
\hline 6.1. & $\begin{array}{l}\text { Identification of pilot projects to transfer digital technologies (implementation) } \\
\text { management know-how from foreign countries that are most relevant for the local } \\
\text { industry and could later lead to whole industrial development }\end{array}$ & K2; K1 \\
\hline 6.2 & $\begin{array}{l}\text { Preparation of measures for the larger-scale implementation of successful pilots of } \\
\text { digital technologies (implementation) management tools }\end{array}$ & K2; K1 \\
\hline 7. & $\begin{array}{l}\text { Continued support of measures for participation in international knowledge } \\
\text { dissemination networks (e.g. exhibitions, trade missions, and through agents) }\end{array}$ & K2; E3 \\
\hline 8. & $\begin{array}{l}\begin{array}{l}\text { Development and implementation of public servants' qualification } \\
\text { improvement and training programmes that cover industry digitisation } \\
\text { challenges }\end{array}\end{array}$ & P1 \\
\hline 9. & $\begin{array}{l}\text { Support measure for the transfer of good practice from foreign countries (e.g. } \\
\text { pilot projects for transfer and adaptation of other countries' good practice; } \\
\text { triple-helix stakeholders' visits to good practice countries to understand the } \\
\text { implementation of policy measures) }\end{array}$ & P1; E3 \\
\hline 10. & $\begin{array}{l}\text { Revision, updating and preparation of study programmes, related to industry } \\
\text { digitisation }\end{array}$ & P2 \\
\hline 11. & Renewal of teaching resources, laboratory equipment and learning tools & P2; I2 \\
\hline 12. & $\begin{array}{l}\text { Development of bachelor and master level digital manufacturing study } \\
\text { programmes and related bridging courses for college graduates }\end{array}$ & $\mathrm{P} 2$ \\
\hline 13. & $\begin{array}{l}\text { Development and implementation of interdisciplinary study programmes (e.g. } \\
\text { Smart Production Technologies \& Robotics, IT \& Robotics, Laser cutting \& } \\
\text { Metalworking) }\end{array}$ & $\mathrm{P} 2$ \\
\hline 14. & $\begin{array}{l}\text { Development and implementation of vocational teachers' and lecturers' } \\
\text { qualification improvement and training programmes that cover industry } \\
\text { digitisation challenges }\end{array}$ & $\mathrm{P} 2$ \\
\hline 15. & $\begin{array}{l}\text { Creation of support measure for the use of infrastructure of business clusters } \\
\text { and open access centres by researchers (e.g. for qualification improvement and } \\
\text { training purposes) }\end{array}$ & P2; E3 \\
\hline 16. & Private/public initiatives to attract talented professionals from abroad & P2; E3 \\
\hline 17. & $\begin{array}{l}\text { Implementation of employee qualification improvement and training in } \\
\text { workplace programmes targeting the application of digital technologies (e.g. by } \\
\text { expanding the apprenticeship/vocational training model to encompass workers } \\
\text { as well as production technologists) }\end{array}$ & P3 \\
\hline 18. & $\begin{array}{l}\text { Recruitment of foreign students who potentially could work in local industry } \\
\text { companies after graduation }\end{array}$ & P3 \\
\hline 19. & $\begin{array}{l}\text { Integration of management and technology transfer study modules in } \\
\text { technological studies (e.g. engineering in digital manufacturing and related } \\
\text { studies) }\end{array}$ & P4 \\
\hline 20. & $\begin{array}{l}\text { Informal education programmes for the training of intermediaries and } \\
\text { possibilities for recognition }\end{array}$ & P4 \\
\hline 21. & $\begin{array}{l}\text { Systemic and regularly performed research in forecasting and prediction of } \\
\text { international value chains trends }\end{array}$ & I1 \\
\hline 22. & $\begin{array}{l}\text { Systemic and regularly performed research to identify industry needs for } \\
\text { support services (e.g. surveying companies, sectoral analysis) }\end{array}$ & I1 \\
\hline 22.1 & $\begin{array}{l}\text { Surveys on funding measures (evaluation of the measures, by surveying } \\
\text { participating companies immediately after a call for proposals ends) }\end{array}$ & I1 \\
\hline
\end{tabular}


INDEPENDENT JOURNAL OF MANAGEMENT \& PRODUCTION (IJM\&P)

http://www.ijmp.jor.br

v. 12, n. 6, Special Edition ISE, S\&P - November 2021

ISSN: 2236-269X

DOI: 10.14807/ijmp.v12i6.1779

\begin{tabular}{|c|c|c|}
\hline 22.2 & $\begin{array}{l}\text { Surveys on technologies for the identification of technologies of current relevance to } \\
\text { companies }\end{array}$ & I1 \\
\hline 22.3 & $\begin{array}{l}\text { Surveys for a sectoral analysis/review of value chains (monitoring and analysis of } \\
\text { existing and future value chains) }\end{array}$ & $\mathrm{I} 1$ \\
\hline 23. & Creation of Digital Innovation Hubs (DIHs) service network & $\mathrm{I} 1$ \\
\hline 23.1 & Pilot measure for the development of DIHs' service infrastructure & $\mathrm{I} 1$ \\
\hline 23.2 & $\begin{array}{l}\text { Mapping of potential DIHs (to identify which organizations can be incorporated or } \\
\text { join DIHs) }\end{array}$ & I1 \\
\hline 23.3 & $\begin{array}{l}\text { Prepare co-financing schemes showing how Moldova will support DIHs accepted } \\
\text { into international networks }\end{array}$ & I1; E3 \\
\hline 23.4 & Permanent measure & I1 \\
\hline 23.5 & $\begin{array}{l}\text { Creation of conditions to connect to public infrastructure and utilities governed by } \\
\text { the state or municipalities (electricity, gas, water, data necessary for Industry 4.0) }\end{array}$ & I1; E2 \\
\hline 24. & Development of $5 G$ network & $\mathrm{I} 1$ \\
\hline 24.1 & Organization of auctions for $5 \mathrm{G}$ frequencies $(3400-3800 \mathrm{MHz}, 700 \mathrm{MHz}$ ) & I1; E2 \\
\hline 24.2 & Allocation of 5G frequencies ( $3400-3800 \mathrm{MHz}, 700 \mathrm{MHz}$ ) for commercial uses & I1; E2 \\
\hline 24.3 & $\begin{array}{l}\text { Review and approval of changes to the hygienic norms of electromagnetic radiation: } \\
\text { increase the radiation threshold to equalize it to the standard acceptable to the rest of } \\
\text { Europe and application of changes to the measurement methodology }\end{array}$ & I1; E2 \\
\hline 24.4 & $\begin{array}{l}\text { Easing of regulations (e.g. elimination of, or reduction in conditions, to receive } \\
\text { permissions, especially in the case of pico- and microcell instalment) }\end{array}$ & I1; E2 \\
\hline 24.5 & $\begin{array}{l}\text { Establishment of opportunities for network operators to use public infrastructure } \\
\text { (e.g. lighting towers, buildings, chimneys, other objects) for instalment of mobile } \\
\text { network elements/equipment with conditions appropriate to support 5G }\end{array}$ & I1; E2 \\
\hline 24.6 & $\begin{array}{l}\text { Development of infrastructure necessary for } 5 \mathrm{G} \text { alongside or during implementation } \\
\text { of governmental/municipal projects regarding transport and energy }\end{array}$ & I1 \\
\hline 24.7 & A developed 5G network & $\mathrm{I} 1$ \\
\hline 25. & Development of digital technology demonstration infrastructure & $\mathrm{I} 2$ \\
\hline 26. & Development of digital technology demonstration infrastructure & $\mathrm{I} 2$ \\
\hline 26.1 & Development of the national digital technology demonstration concept & I2; E1 \\
\hline 26.2 & $\begin{array}{l}\text { Virtual factory (e.g. an interactive platform or a webpage with remote control and } \\
\text { simulations of technologies) }\end{array}$ & $\mathrm{I} 2$ \\
\hline 26.3 & A measure for the development of 'digital twins' in factories & I2; E3 \\
\hline 26.4 & $\begin{array}{l}\text { Demonstration of exemplary digital technologies and digitisation solutions based on } \\
\text { national and international good practice }\end{array}$ & I2; K1 \\
\hline 26.5 & $\begin{array}{l}\text { Transfer of good practice from abroad (e.g. a technology demonstration centre, } \\
\text { where various technological solutions offered by a number of companies, and their } \\
\text { integration possibilities, are demonstrated on one site) }\end{array}$ & I2; K1 \\
\hline 26.6 & $\begin{array}{l}\text { Creation of } 2 \text { exemplary physical digital technology demonstration centres alongside } \\
\text { developers of digital technologies }\end{array}$ & $\mathrm{I} 2$ \\
\hline 27. & $\begin{array}{l}\text { Investment in Digital Innovation Hubs' (DIHs') infrastructure necessary for the } \\
\text { development of digital technologies }\end{array}$ & I3 \\
\hline 27.1 & $\begin{array}{l}\text { Pilot measure for the development of DIHs' innovation and R\&D infrastructure for } \\
\text { digitisation services }\end{array}$ & I3 \\
\hline 27.2 & Support for 4-5 infrastructure development projects for DIHs & I3 \\
\hline 28. & Introduction of guidelines for IT/R\&D public procurement procedures & I3; E1 \\
\hline 29. & $\begin{array}{l}\text { A continued development of clusters' shared access centres for innovation and } \\
\text { R\&D }\end{array}$ & I3 \\
\hline 30. & $\begin{array}{l}\begin{array}{l}\text { Development of technology prototyping, testing and pilot production } \\
\text { infrastructure }\end{array} \\
\end{array}$ & I3 \\
\hline 30.1 & Support for 4-5 infrastructure development projects for prototyping, testing and pilot & I3 \\
\hline
\end{tabular}


INDEPENDENT JOURNAL OF MANAGEMENT \& PRODUCTION (IJM\&P)

http://www.ijmp.jor.br

v. 12, n. 6, Special Edition ISE, S\&P - November 2021

ISSN: 2236-269X

DOI: 10.14807/ijmp.v12i6.1779

production

30.2 Support for the development of 4-5 competence centres running on an open access model in the topic areas related to DIHs' activities

31. Creation of industry transformation strategy

32. Innovation system reform concerning industry digitisation

33. Refinement of work relations regulations

34. Issuance of regulation regarding service provision by Open Access Centres (OACs)

35. Preparation of Digital Innovation Hubs (DIHs) development concept

36. Establishment and/or enforcement of regulation in intellectual property dispute resolution - e.g. between researchers and universities, between customers (businesses) and executors (universities)

37. Introduction of regulation for technology demonstration equipment use and accounting (i.e. amortization, deductible expenses issues)

38. Elimination of obstacles to universities and research institutes managing held infrastructure (land, buildings, equipment)

39. Development and implementation of standards to support industry digitisation

39.1 Recognition of researchers' contribution to standardization work (similar to traditional scientific publications)

39.2 Legislation to promote the application of standardisation as an instrument for innovation development and economic growth

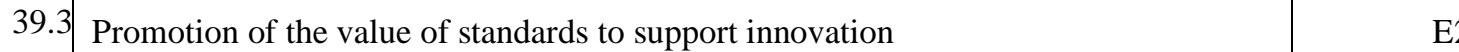

39.4 Implementation of standards associated with industry digitisation $\quad$ E2

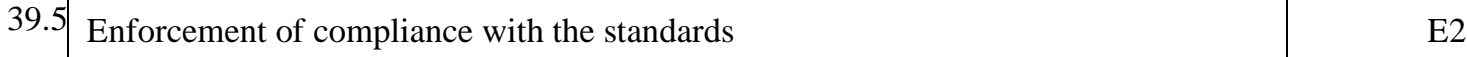

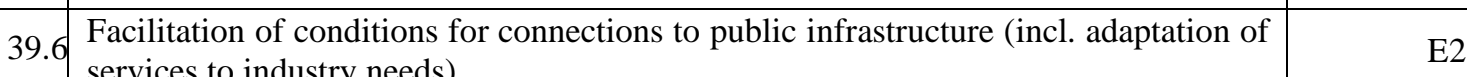

40. Promotion of interoperability $\quad$ E2

\begin{tabular}{l|l|l} 
41. Building blocks for national and cross-border G2B services & E2
\end{tabular}

\begin{tabular}{l|l|l}
41.1 & Preparation of usability guidelines for Industry 4.0 & E2; E1
\end{tabular}

\begin{tabular}{|l|l|l}
\hline 41.2 & Enforcement of compliance with the usability guidelines & E2; E1
\end{tabular}

42. Development of tax reliefs for promotion of industry digitisation $\quad$ E3

42.1 $\begin{aligned} & \text { Creation of tax reliefs for accelerated capital allowance and hyper and/or super- } \\ & \text { depreciation of tangible and intangible assets related to digital technologies }\end{aligned} \quad$ E3

\begin{tabular}{l|l|l}
42.2 & Extension of a current tax relief regarding asset depreciation after the year 2023 & E3
\end{tabular}

\begin{tabular}{l|l|l}
42.3 & Implementation & E3
\end{tabular}

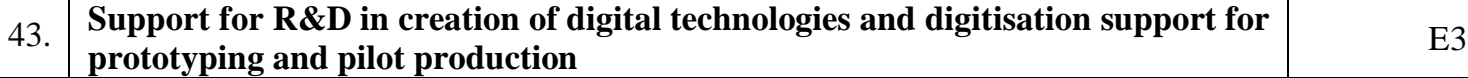

43.1 Preparation of support schemes for $\mathrm{R} \& \mathrm{D}$, prototyping and pilot production in $\quad$ E3

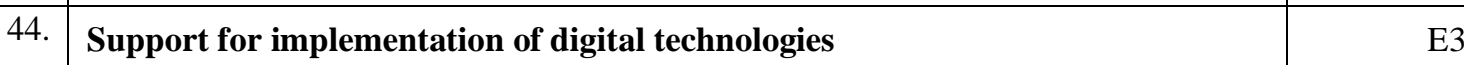

\begin{tabular}{l|l|l}
44.1 & Preparation of support schemes for implementation of digital technologies & E3
\end{tabular}

\begin{tabular}{l|l|l}
44.2 & Support projects & E3
\end{tabular}

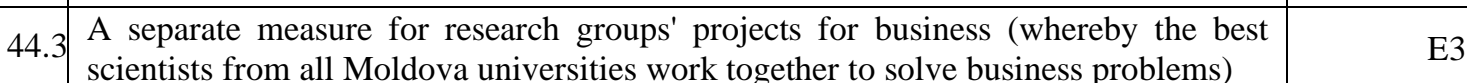

45. Support for companies in the purchasing of services related to digitisation (e.g. $\quad$ E3

\begin{tabular}{|l|l|l} 
& in the form of service bundles/service packages, cheques) & \\
\hline 45.1 & Technology vouchers as a measure for production digitisation & E3
\end{tabular} 
INDEPENDENT JOURNAL OF MANAGEMENT \& PRODUCTION (IJM\&P)

http://www.ijmp.jor.br

v. 12, n. 6, Special Edition ISE, S\&P - November 2021

ISSN: 2236-269X

DOI: 10.14807/ijmp.v12i6.1779

\begin{tabular}{|c|l|c|}
\hline 45.2 & Support projects & E3 \\
\hline 46. & Uninterrupted support for digitisation and/or technological audits (vouchers) & E3 \\
\hline 46.1 & $\begin{array}{l}\text { Preparation of support schemes for digitisation and/or technological audits } \\
\text { (vouchers) }\end{array}$ & E3 \\
\hline 46.2 & Implementation & E3 \\
\hline 47. & $\begin{array}{l}\text { Support for attracting and retaining specialists, professional internships, } \\
\text { qualification improvement, training and retraining }\end{array}$ & E3; P2; P3 \\
\hline 47.1 & $\begin{array}{l}\text { Preparation of schemes for training a workplace (apprenticeship/vocational } \\
\text { training) to obtain knowledge in working with digital technologies }\end{array}$ & E3; P2; P3 \\
\hline 47.2 & A voucher for the development of skills in working with digital technologies & E3; P2; P3 \\
\hline 47.3 & $\begin{array}{l}\text { Implementation } \\
\text { 48. }\end{array}$ & $\begin{array}{l}\text { Support for expansion of Digital Innovation Hubs (DIHs) and integration in } \\
\text { national and international networks }\end{array}$ \\
\hline 48.1 & Preparation of a measure for the extension of DIHs & E3; I1 \\
\hline 48.2 & Implementation & E3; I1 \\
\hline
\end{tabular}

\section{CONCLUSIONS AND RECOMMENDATIONS}

The country's competitiveness is directly proportional to the country's level of economic development. According to SWOT analysis, general strengths on which Moldovan industry digitalisation will rely can be distinguished. It relies on the fact that manufacturing sector output is increasing - the contribution of the manufacturing sector to national GDP is around $12 \%$, however it is on the lower side compared to other EU countries. Despite that, recent years indicate the rise of the output of this industry segment and industry digitisation will further encourage this process.

Secondly, public and private IRT infrastructure is well-developed - is consistently updated, provides world-class internet access, and allows faster digitization. Thirdly, the growing capacity of digitization solutions providers - supply a wide range of services by participating in local and global value chains.

Industry digitalization will address weaknesses such as SMEs dominate the local industry with low-level technology readiness, which currently limits investment in the overall advancement of manufacturing.

Secondly, production is dominated by contract manufacturing of low value-added products, which limits the need for cutting-edge technological solutions and does not require much cooperation between Moldovan research and industry.

Thirdly, discrepancies appeared between academia and industry's needs and the digitization incentives system is fragmented and has many elements with poorly functioning 
INDEPENDENT JOURNAL OF MANAGEMENT \& PRODUCTION (IJM\&P)

http://www.ijmp.jor.br

v. 12, n. 6, Special Edition ISE, S\&P - November 2021

ISSN: 2236-269X

DOI: 10.14807/ijmp.v12i6.1779

links between them. Moreover, partnership culture develops slowly and hinders collaboration and cooperation between major actors in the ecosystem and ordinary B2B relationships.

Implementing these measures are expected to grant the following benefits:

- Higher rankings/better ratings across a range of indicators that measure the state's performance in digitization and/or innovation at European level and globally

- An increased number of companies carrying out innovation activities

- An increased number of companies that benefit from tax reliefs

- A growing share of GDP generated by high-tech companies

- An increasing number of employees working in high-tech companies

- A more effective innovation system

- Better adaptation to pan-European and global standards

- New services for businesses

- The national network of Digital Innovation Hubs that provide specialized digitization services

- An increased ratio of medium to high-tech companies compared to all companies

- An increased number of registered patents

- A reduced regulatory burden for companies carrying out innovation activities

- An increased number of PhDs working in the field of industry digitization

- Reviewed and updated study programmers

- New and interdisciplinary study programmers in relation to industry digitization

- New scientific and technology demonstration equipment

- An increased number of professionals attracted to industry from abroad

- Increased private company investments in innovation activities

- Increased added-value generated by manufacturing enterprises

- Increased manufacturing companies' turnover

- An increased number of projects funded via public-private partnerships

- An increase of exports in identified value chains

- An increased number of companies that benefited from state support to get involved in international value chains.

\section{REFERENCES}

Balabash O., Ilin V., Poprozman N., Kuznetsova I., Shushpanov D., \& Slavina N. (2021). Content Strategy in Management of Communications. Independent Journal of 
INDEPENDENT JOURNAL OF MANAGEMENT \& PRODUCTION (IJM\&P)

http://www.ijmp.jor.br

v. 12, n. 6, Special Edition ISE, S\&P - November 2021

ISSN: 2236-269X

DOI: 10.14807/ijmp.v12i6.1779

Management \& Production, 12(3), s232-s242.

DOI: https://doi.org/10.14807/ijmp.v12i3.1538.

Bickauske, D., Simanaviciene, Z., Jakubavicius, A., Vilys, M. \& Mykhalchyshyna, L. (2020). Analysis and Perspectives of the Level of Enterprises Digitalization (Lithuanian Manufacturing Sector Case). Independent Journal of Management \& Production, 11(9), 2291-2307. DOI: http://dx.doi.org/10.14807/ijmp.v11i9.1404

Bogner, A., Littig, B., \& Menz, W. (2009) Introduction: Expert Interviews - An Introduction to a New Methodological Debate. Palgrave Macmillian, New York, 1-13, 2009. DOI: 10.1057/9780230244276_1

Competitive Industrial Performance Index (2020). UNIDO Statistics Data Portal. Available online: http://stat.unido.org/country/MDA.pdf

Duarte, C., \& Ebert, C. (2018). Digital Transformation. IEEE Software. 35. 16-21. DOI: 10.1109/MS.2018.2801537.

Esser, K., Hillebrand, W., Messner, D. \& Meyer-Stamer, J. (2008). Systemic

Competitiveness: a New Challenge for Firms and for Government. Milestones in a Process of Innovation, Change and Development. Special Edition: Buenos Aires/Dortmund, 2126.

Filó, C. (2007). Territorial Competitiveness and the Human Factors. International Conference of Territorial Intelligence, Huelva 2007 (CAENTI). Retrieved from http://www.territorial-intelligence.eu. Access: 12 July, 2021.

Global Competitiveness Index report, (2019). World Economic Forum. Retrieved from http://www3.weforum.org/docs/WEF_TheGlobalCompetitivenessReport2019.pdf. Access: 29 July, 2021.

Hoellthaler, G., Braunreuther, S., \& Reinhart, G. (2018). Digital Lean Production an Approach to Identify Potentials for the Migration to a Digitalized Production System in SMEs from a Lean Perspective. Procedia CIRP, 67, 522-527. DOI: 10.1016/J.PROCIR.2017.12.255.

Kallioras, A., Pliakas, F., Diamantis, I., \& Kallergis, G. (2010). SWOT analysis in groundwater resources management of coastal aquifers: a case study from Greece. Water Int., 35(4), 425-441. DOI:10.1080/02508060.2010.508929.

Kilimis, P., Zou, W., Lehmann, M., \& Berger, U. A. (2019). Survey on Digitalization for SMEs in Brandenburg, Germany, IFAC-PapersOnLine, 52 (13), 2140-2145.

Krugman, P. (1994). Competitiveness: a Dangerous obsession. In: Competitiveness. An International Economics Reader, N.Y.: Foreign Affairs, 1994, P. 1-17.

Leão de Miranda, R., Irgang dos Santos, L. F., Giancarlo Gomes, G., \& dos Santos Parisotto, I. R. (2021). Competitivness influence on global innovation of nations: a cross-sectional analysis. Independent Journal of Management \& Production, 12(4), 964-978. DOI: 10.14807/ijmp. v12i4.1338.

Mainali, B., Ngo, H., Guo, W., Pham, T., Wang, X. C., \& Johnston, A. (2011). SWOT analysis to assist identification of the critical factors for the successful implementation of water reuse schemes. Desalin Water Treat, 32(1-3), 297-306. DOI:10.5004/dwt.2011.2714.

Marinović Matović, I. (2017). Impact of refugee crisis on tourism development: Evidence from Republic of Serbia. Second International Thematic Monograph - Thematic 
INDEPENDENT JOURNAL OF MANAGEMENT \& PRODUCTION (IJM\&P)

http://www.ijmp.jor.br

v. 12, n. 6, Special Edition ISE, S\&P - November 2021

ISSN: 2236-269X

DOI: 10.14807/ijmp.v12i6.1779

Proceedings: Modern management tools and economy of tourism sector in present era, Belgrade, pp. 628-644.

Okano, M. T., Antunes, S. N., \& Fernandes, M. E. (2021). Digital transformation in the manufacturing industry under the optics of digital platforms and ecosystems. Independent Journal of Management \& Production, 12(4), 1139-1159.

DOI: https://doi.org/10.14807/ijmp.v12i4.1375.

Porter, M. E. (1980). Competitive strategy: Techniques for analyzing industries and competitors. In: New York: free press.

Porter, M. E. (1990). The competitive advantage of nations. Harvard Business Review. In: March-April.

Porter, M., E. (2012). Regional Competitiveness and the Role of Business. Harvard

Business School, Mexico. Access: 15 July, 2021. http://www.isc.hbs.edu/pdf/2012-0427--Michael_Porter_Puebla.pdf.

Puraite, A., Zuzeviciute, V., Bereikiene, D., Skrypko, T., \& Shmorgun, L. (2020).

Algorithmic Governance in Public Sector: Is Digitization a Key to Effective Management.

Independent Journal of Management \& Production, 11(9), 2149-2170. DOI:

http://dx.doi.org/10.14807/ijmp.v11i9.1400.

Rakauskiene G., \& Tamošiūnienè, R. (2013). Factors influencing national competitiveness.

Business: Theory and Practice, 14(3), 177-187.

Schallmo D., Williams C., \& Boardman, L. (2018). Digital Transformation of Business Models. Best Practice, Enabler, and Roadmap. International Journal of Innovation Management, 21(8), 1740014. DOI: https://doi.org/10.1142/S136391961740014X.

Ślusarczyk, B. (2018). Industry 4.0 - Are we ready? Polish Journal of Management

Studies, 17(10), 232-248. DOI:10.17512/pjms.2018.17.1.19.

Smith, A. (1937). An Inquiry into the Nature and Causes of the Wealth of Nations. The Modern Library.

Statbank (2020). Statistical databank. Retrieved from http://statbank.statistica.md/pxweb/pxweb/en/40\%20Statistica\%20economica/40\%20Statistic a\%20economica_13\%20CNT_SCN2008_CNT010_Resurse/CNT010072.px/table/table ViewLayout1/?rxid=9a62a0d7-86c4-45da-b7e4-fecc26003802\%22\%20class=\%22link_mail.

Statbank, (2020a). Statistical databank. Retrieved from

http://statbank.statistica.md/pxweb/pxweb/en/40\%20Statistica\%20economica/40\%20Statistic a\%20economica_14\%20IND_IND020/IND020100.px/table/tableViewLayout1/?rxid=b2ff 27d7-0b96-43c9-934b-42e1a2a9a774. Access: 19 July, 2021.

Statbank, (2021). Statistical databank. Retrieved from http://statbank.statistica.md/pxweb/pxweb/en/40\%20Statistica\%20economica/40\%20Statistic a\%20economica_14\%20IND_IND010_serii\%20anuale/IND010200.px/table/tableViewL ayout1/?rxid=ff9b9e33-ef0e-4a49-b838-bd2be6251594. Access: 17 July, 2021.

The Global Competitiveness Report 2017-2018, World Economic Forum 2017. Retrieved from https://www.weforum.org/reports/global-competitiveness-report-2017-2018. Access: 10 July, 2021.

Ulas, D. (2019). Digital Transformation Process and SMEs. Procedia Computer Science, 158, 662-671. 
Wang, S., Wan, J., Zhang, D., Li, D., \& Zhang, C. (2016). Towards smart factory for industry 4.0: a self-organized multi-agent system with big data-based feedback and coordination, special issue: Industrial Technologies and Applications for the Internet of Things, 101, 158-168. DOI: https://doi.org/10.1016/j.comnet.2015.12.017.

World Competitiveness Ranking, The Institute for Management Development (IMD), 2017. Retrieved from https://www.imd.org/centers/world-competitivenesscenter/rankings/world-competitiveness/. Access: 15 July, 2021.

World Digital Competitiveness Ranking, The Institute for Management Development. Retrieved from https://www.imd.org/centers/world-competitiveness-center/rankings/worlddigital-competitiveness/. Access: 14 July, 2021.

World Digital Competitiveness WDC (2017). The Institute for Management Development. Retrieved from https://www.imd.org/centers/world-competitiveness-center/rankings/worlddigital-competitiveness/. Access: 12 July, 2021.

Zalizko, V. D., Kanan, S. H., \& Poprozman, N. V. (2018). Economic and Financial Security of Azerbaijan in the Context of Institutional Convergations. Financial and Credit ActivityProblems of Theory and Practice, 2(25), 278-287. DOI: 10.18371/FCAPTP.V2I25.136867. 